\title{
Chapter 11 \\ The Spanish Response to the Covid-19 \\ Pandemic: From Joint Governance \\ to Lack of Governance
}

\author{
Javier M. Valle and Carlos de Olagüe-Smithson
}

\begin{abstract}
On March 9, 2020, to safeguard the health of the population from the spread of COVID-19, the Autonomous Community of Madrid was the first region in Spain to suspend in person classroom activity from March 11th. Five days later, on March 14th, the Spanish government declared a state of emergency and in person classroom lessons were suspended throughout the country.
\end{abstract}

This chapter will analyze the Spanish national response to the pandemic, comparing the approaches of the 17 Spanish Autonomous Communities and focusing on the details of the first region to suspend classroom education, the Autonomous Community of Madrid, the capital.

In many cases, teachers and schools reacted quickly to try to maintain educational continuity for the students through self-instructional courses and procedures for distance learning. The public education administration did not promptly provide clear guidelines, in part due to the Spanish decentralized government structure. By April 2020, distance learning was already offered at most of schools.

In July 2020, the EvAU- the national state exam that provides access to university studies - was administered to students in person, following strict health care protocols including mandatory mask mandates, hand sanitizer at the entrance and exit of the classrooms, and a distance of $1.5 \mathrm{~m}$ between desks. The pandemic in Spain has fostered ICT skills in an unprecedented way. For example, teachers and students have embraced a new way of teaching and learning (with private platforms like Google Classroom and Microsoft Teams). This development of ICT skills and a new focus on competences appears to have changed Spanish education in a never-before-seen way and might have a long-term impact.

\footnotetext{
J. M. Valle (凶)

Universidad Autónoma de Madrid, Ciudad Universitaria de Cantoblanco, 28049 Madrid, Spain e-mail: jm.valle@uam.es

C. de Olagüe-Smithson

IES Pedro de Tolosa, c/Estudios 1, 28680 San Martín de Valdeiglesias, Madrid, Spain

e-mail: colaguesmithson@educa.madrid.org
} 


\subsection{Introduction Organization, Structure, and Legal Framework of the Spanish Education System}

After the dictatorship of Francisco Franco (1939-1978), Spain began a democratic process affecting all social and political domains. The education system, as part of this transformation, was reformed with laws proposed by different administrations representing different ruling parties and coallitions. ${ }^{1}$

With democracy established by the 1978 Constitution, it became essential to reform the system to align it with the new democratic political situation. These reforms, based on new constitutional values, opened the system to the principles of decentralization, democratization, and participation (Egido, 2005).

Before democratization, the educational system in Spain was one of the most centralized in Europe, but it was transformed to distribute the responsibility of education among the Central Government and the 17 autonomous regions-Comunidades Autónomas-(Autonomous Communities). According to the general framework of the central legislation, these territories have the authority to manage their respective region's educational system. Those territories which have an official regional language can use it as the language of instruction.

Many laws were oriented to modernize the educational system during the years after the approval of the 1978 Spanish Constitution. These laws were passed by different governments of the two main national political parties, advancing goals and norms of opposite orientation to guide the Spanish education system, which as a result experienced alternating changes introduced by administrations with different political orientations.

These education reforms began under the Socialist Party (1982-1996) with the University Reform Act (Ley de Reforma Universitaria, LRU) of 1983. This Act updated the Spanish University system and was based on three constitutional principles: the universal right to education, academic freedom, and the autonomy of universities. In 1985, the constitutionally recognized educational rights and liberties were regulated in stages, including tertiary education and University level by the Organic Act of Right to Education (Ley Orgánica Reguladora del Derecho a la Educación,LODE). This law attempted to democratize the management of educational institutions and establish school councils in educational institutions and autonomous communities, and at a national level. Furthermore, this law implicated one of the most repeated and controversial educational debates in Spain: the status, management, and funding of private schools. The Act upheld the right to create private educational institutions, which are private institutions that could receive public funding under certain conditions described in the law. As a result, private schools-mainly owned by the Catholic Church and culturally important since the nineteenth century - were among the academic institutions that could be financed by the State (Ossenbach, 1996). During the academic year 2019-2020, according to

\footnotetext{
${ }^{1}$ Egido \& Valle (2015) provide a detailed description of the recent history of education in Spain and summarize the main parts of its academic structure. An extended version of the following explanation can be found in the mentioned text.
} 
official statistics regarding non-tertiary education, 5,381 out of 9,390 private schools were financed by the State, out of a total number of 19,149 schools.

In 1990, the transformations of the organization, administration, and management of the education system were complemented by the modification of the structure of all educational levels and their curricula by the Organic Act on the General Organization of the Educational System (Ley Organica de Ordenación General del Sistema Educativo, LOGSE). This law introduced an important structural change and a more flexible curriculum, inspired by the principles of constructivist educational theories. The law also extended universal compulsory education up to age sixteen, establishing a model with ten years of comprehensive education (de Olagüe-Smithson, 2019, p. 133).

At the beginning of the twenty-first century, the conservative party (Partido Popular) introduced another set of reforms to the educational system. The Organic Act on Universities of 2001 (Ley Orgánica de Universidades, LOU) repealed the University Reform Act (LRU) and regulated the structure and organization of the educational system at the university level. The Act on Vocational Training and Professional Qualifications of 2002 modified the LOGSE concerning these modalities of education. Also in 2002, the Organic Act on Quality of Education (Ley Orgánica de Calidad de la Educación, LOCE), modified both the LODE and the LOGSE. The objective of the LOCE was to increase the quality and the performance of education. However, this law was not implemented due to a change in government which took place in 2004.

Upon the election of the new socialist government (2004-2011) the law was modified again in 2006 through the Organic Act on Education (Ley Orgánica de Educación, LOE), which regulated the Spanish non-university educational system until December 2013. Additionally, the Organic Act on Universities was amended to align the Spanish university education with the European Higher Education Area (EHEA) in 2007 (Organic law 4 of April 12, 2007, which modifies Organic Law 6 of December 21, 2001).

\subsection{The Current Educational System in Spain}

After almost eight years of socialist government, the 2011 election gave the conservative party the absolute government majority. In December 2013, this new government approved the Act on the Improvement of the Quality of Education (Ley Orgánica de Mejora de la Calidad Educativa, LOMCE) to again modify the educational system. This law affected the levels below tertiary education, prioritizing the improvement of educational quality, the increase of youth employability, the modernization of vocational training, and the reduction of drop-out rates. ${ }^{2}$ Although this Act intended to modify the LOE of 2006 only slightly, the measures were strongly criticized across

\footnotetext{
${ }^{2}$ Early leavers' rate was $31 \%$ in 2002 ; it remains in $17 \%$ in 2019, far from the European Union target for under $10 \%$ by 2020 .
} 
different sectors. The Act had no broad political consensus and was only supported by the government's majority party. Most of the opposition parties opposed the law.

In December 2020, the coalition government of the socialists and communists elected in 2019 passed the new Act “Ley Orgánica 3, 2020” (BOE, 2020).

These frequent changes to the legal framework constitute one of the main challenges for educational policy in Spain: the lack of stability and continuity resulting from an elusive education consensus between the main political parties in Spain. The resulting short policy cycles are seen as a problem by different education stakeholders including teachers' and parents' associations, but also academics and specialized media. For example, the President of the Spanish Federation of Public Schools Principals' Associations said that they deeply regret the lack of consensus in passing the new law of education, and they encourage political parties and educational communities to work together to avoid more reforms without consensus in the future. ${ }^{3}$

The abundance of education laws since 1990 (and their corresponding regulatory developments) and the continuous legislative changes and lack of policy continuity have produced teacher fatigue and confusion for parents and society. While politics often influences educational changes, in the case of Spain, these political fluctuations have resulted in a failure to achieve a national consensus and stability for education. It has not been possible to consolidate a stable regulatory framework, nor permanent laws, and consequently there has not been steady education development (Antiñolo, Molina, \& Pérez, 2014).

However, despite the proliferation of educational laws, some characteristics of the educational system have remained relatively stable; some of the guidelines for the progress of Spanish education have remained unchanged over the last few decades. Two among these help understand the Spanish educational response to the COVID-19 pandemic: (1) the educational administration model and (2) the overall organization of the different levels of education.

Concerning the school system administration model, powers and responsibilities are shared between the State and the Autonomous Communities. According to the Spanish Constitution, Article 139.1.30 (Constitución Española, 1978), the State is responsible for ensuring basic minimum program standards (curriculum and qualifications) across Spain and guaranteeing the educational rights of Spanish citizens. That is why the State plays the primary regulatory role on educational issues, but Autonomous Communities are uniquely responsible for the administration and organization of the educational system in their respective regions, save the powers reserved to the State. Autonomous Communities regulate school programs beyond the minimum structure and content determined by the State and handle school personnel, grants, and support services. Nevertheless, despite the changes meant to decentralize the educational system, local government authorities and individual schools play a limited role. Officially, schools have certain pedagogical, organizational, and managerial autonomy, but the decentralization process has not fully empowered these educational institutions. Spanish schools are characterized by

3 https://www.europapress.es/sociedad/educacion-00468/noticia-directores-instituto-lamentanfalta-consenso-aprobacion-ley-celaa-congreso-20201119165259.html. 
limited autonomy, whereas most decisions are made by the educational administration. As a result, schools do not have the ability to effectively adapt to changing environments and policy priorities (Egido, 2005). In the pandemic context, schools have been paralyzed, without the autonomy to offer contextualized responses; they completely depended on the state and regional education authorities that offered slow and contradictory guidelines.

The structure of the educational system has remained relatively stable since 1990, despite the multitude of laws that have changed curriculum and school organization. The structure contains five levels: Infant Education, Primary Education, Compulsory Secondary Education, Upper Secondary Education and Higher Education. The first stage in the general educational system is Infant or Pre-primary Education and it is not compulsory. It has two levels: from age 0 to 3 and from age 3 to 6 , the latter of which is free in all publicly funded schools. Primary Education is the first compulsory stage and lasts six years, between the ages of 6 and 12. Compulsory Secondary Education (Educación Secundaria Obligatoria, ESO) is the second compulsory stage and covers four school years, for pupils between the ages of 12 and 16. Together Primary Education and Compulsory Secondary Education constitute the "Basic Education", ten years of free and compulsory education for all students.

After compulsory education, pupils can access Upper Secondary Education that is also offered in Secondary Schools. It lasts two academic years, usually studied between the ages of 16 and 18. It is offered at Vocational Training integrated institutions and in national reference institutions, and it also offers two pathways: Bachillerato (mainstream branch of general upper secondary) and Intermediate Vocational Training (professional branch or technical upper secondary).

Finally, Higher Education includes university and non-university tertiary education. University studies, include Bachelors, Masters and Doctoral Degrees as established by the integration of Spain in the European Higher Education Area (EHEA). Non-university tertiary education includes Advanced Vocational Training and Specialized tertiary education. Although Spain's tertiary educational system consists of both university and non-university institutions, it operates - unlike other European systems - as a system primarily consisting of university institutions (OECD, 2009).

\subsection{The Response to the Pandemic and the Impacts on Education}

On March 9, 2020, to safeguard the health of the population from the spread of COVID-19, the Autonomous Community of Madrid was the first region in Spain to establish extraordinary measures to handle the coronavirus disease (COVID-19) pandemic (Comunidad Autónoma de Madrid, 2020). One of the primary actions was the decision to suspend classroom activity at all levels, from formal education to its complementary educational activities. The regional government recommended 
resuming teaching online. Presuming a mitigated epidemic spread, schools were expected to reopen on March 26th.

On March 14th, the Spanish government with the Royal Decree 463/2020 declared a state of emergency to manage the health crisis created by COVID-19 (Boletín Oficial del Estado, 2020). Article 9 suspended face-to-face educational activity in all institutions and stages, cycles, degrees, courses, and academic levels included in article 3 of the Organic Law 2/2006 of Education (BOE, 2006), including university and all other teaching activities in public or private centers. During the suspension period, the educational activities were to be offered, if possible, remotely.

According to Zubillaga and Gortazar (2020) these measures affected nearly 10 million students in Spain and exacerbated problems in the Spanish educational system. The switch to online teaching was immediate and abrupt with no time for teachers to plan and design new learning procedures; it became an Emergency Remote Teaching experience, like the situation in other countries around the world (Hodges, Moore, Lockee, Trust, \& Bond, 2020).

This sudden transition of the teaching model highlighted several systemic gaps (Fernández Enguita, 2020):

- Access gap: as some students lacked an internet connection and electronic equipment at home. According to the National Institute of Statistics (INE) in 2019, $90 \%$ of the children between the ages of 10 and 15 in Spain have a computer at home and $93 \%$ of them have used internet during the last 3 months. $66 \%$ of these teenagers own a mobile phone. These figures suggest that Spanish youth had sufficient equipment to participate in online classes.

- Students' usage gap: stemming from lack of students' ICT (information and communication technology) literacy and capacity to use different hardware and software tools to learn. According to the European Monitor for Education and Training (November 2020), ${ }^{4} 15 \%$ of European students do not have sufficient digital competencies.

- Teachers ICT gap: stemming from the combination of insufficient teachers' ICT training and lack of proficiency in the use of online platforms and interactive audiovisual material. $50 \%$ of the school principals mentioned that teachers in their schools had the capacity and resources needed to teach online (Zubillaga \& Gortazar, 2020). However, families had difficulty sharing their time and ICT resources; parents had to simultaneously telework while the children attended online schooling (Santos-Montealegre, 2020, p. 87).

The Vice Councils of Education Policies and Organization of the Autonomous Community of Madrid published on March 10th instructions for the education centers to establish rules to continue with distance and online teaching (VICECONSEJERÍAS DE POLÍTICA EDUCATIVA Y DE ORGANIZACIÓN EDUCATIVA 2020, March 10). Seven instructions established that all personnel should continue attending the schools (except infant schools) and teleworking should be

4 https://op.europa.eu/en/publication-detail/-/publication/15d70dc3-e00e-11e9-9c4e-01aa75ed7 1a1/language-en/format-PDF/source-171178208. 
promoted (as long as it was compatible with the continuation of the academic activities). The teachers should adapt their academic program to include home-based activities. The High Schools should pay special attention to students preparing the "Evaluación del Bachillerato para el Acceso a la Universidad (EBAU)," the Spanish official university entrance exam. Teachers maintained contact with students and parents through the Learning Management System LMS platform EducaMadrid, the schools' websites, the Enterprise Resource Planning (ERP) for education platform Roble, email, and other communication methods (including Google Classroom and WhatsApp).

Several teacher unions and labor organizations protested about these guidelines because they forced personnel to attend the schools without sufficient health protection measures. The following day, the Vice Councils published a modification "promoting teleworking," but did not comment on whether academic activities should be guaranteed (VICECONSEJERÍAS DE POLÍTICA EDUCATIVA Y DE ORGANIZACIÓN EDUCATIVA, $2020 \mathrm{~B})$.

During the following weeks, institutions across the country discussed different teaching scenarios, but the direct responsibility for real time decisions was left to the school management boards, even though they were not legally entitled to it.

The schools supported their communities to lessen the impact of the sudden shortage of resources: e.g., donated cleaning material, used 3-D printers to make face protection equipment, ${ }^{5}$ and volunteered health care students at hospitals and elderly residences.

During this period, the Education Council of the State published two proposals: a brief list on March 20th and an extended version on April 7th (Consejo Escolar del Estado, 2020), which suggested two possible scenarios:

- Classrooms lessons might resume before the end of the school year. In this case, teaching should focus on essential contents and basic competencies. The lessons not easily learned at home would not be reflected on students' final grades. Disadvantaged families should have a fair access to education in these conditions.

- Online teaching continues until the next school year.

This is the scenario which was adopted. In this case, the Council urged the administration to provide tools to evaluate the students remotely. It also proposed to only consider academic performance in the first two trimesters (before the pandemic) to determine whether students had successfully completed level 4th ESO (last compulsory secondary education level) and 2nd Bachillerato (University studies entry level).

The Education Council of the State $^{6}$ also recommended other provisions:

EBAU university entrance exam: Establish common criteria among all Autonomous Communities about the structure and contents of the exam.

\footnotetext{
5 https://www.educaciontrespuntocero.com/noticias/profesores-fabrican-mascaras-protector as- $3 \mathrm{~d} /$.

${ }^{6}$ The Scholar Council of the State includes stakeholders in education. The council regularly analyzes the situation of education in Spain and offers its opinion.
} 
Vocational Education and Training: The compulsory workplace learning should be reduced and substituted, if possible, by online alternatives.

Special Needs Education: The Councils recommended that the public administration provide measures to prevent infections, while increasing the material and human resources at these schools.

The Council urged the administration and the media to publicly recognize the efforts of the teachers, families, and students to maintain academic activities during the very complicated conditions created by the pandemic.

In Madrid, new instructions concerning the third trimester and the end of the school year were not published until April 21st (VICECONSEJERÍA DE POLÍTICA EDUCATIVA, 2020). In these instructions, the Autonomous Community of Madrid established that teaching should address all competencies and contents in the courses, including those planned to be taught during the third trimester, which contradicted with the recommendations of the Education Council of the State. Other autonomous communities did not focus on teaching new content and used the time to review previously taught skills and material.

Every April, evaluation exams of the last courses of primary and secondary education are carried out nationwide. In 2020, these exams were canceled (MEFP, 2020).

In May, the pandemic restrictions began to ease. Orders SND/399/2020 and SND/414/2020 of the Ministry of Health described the guidelines to limit risks. Two stages, Phase 0 and 1, established that in person classroom instruction could resume, but the orders did not mention specific rules for schools to follow. This situation created confusion in schools because there were no clear guidelines to follow.

On May 17th, Madrid published instructions to adapt education to the new situation (VICECONSEJERÍAS DE POLÍTICA EDUCATIVA Y DE ORGANIZACIÓN EDUCATIVA, 2020). These instructions transcribed the former orders of the Ministry of Health and made the principals of the schools responsible for the health protection of the academic community. However, once again, the instructions did not provide detailed rules to follow during classroom instruction, for example. The administration did not provide any extra resources to help schools adopt health protocols for in person instruction.

On May 22nd, new instructions for student and teacher examinations and evaluations were published (DIRECCIÓN GENERAL DE EDUCACIÓN SECUNDARIA, FORMACIÓN PROFESIONAL Y RÉGIMEN ESPECIAL, 2020). The deadline for these actions was June 16th.

At the end of May 2020, the health situation had improved, and the Autonomous Community of Madrid wanted to resume in person classroom education in June. The instructions from May 27th urged schools to organize support classes, mainly for students in 2nd Bachillerato that had to prepare the EBAU exam that would take place in July (originally planned for the beginning of June).

As mentioned, in Spain, the responsibility for educational matters has been transferred to the 17 Autonomous Communities. To try and set common policies and 
guidelines, the communities worked together with the national Ministry of Education and Vocational Education and Training in an advisory board named Sectorial Conference on Education. After the session held by this board on June 11th, on June 22nd, the Ministry established and published the measures for prevention, hygiene, and health promotion against COVID-19 at education centers for the school year 2020-2021 (MEFP, 2020 B).

This document had two objectives:

(1) Create healthy and secure school environments with prevention, hygiene, and health promotion measures.

(2) Enable an early detection of cases and their adequate management with clear protocols and promote the coordination of stakeholders.

This document established four key guidelines:

(1) Limitation of contact with others, separating $1.5 \mathrm{~m}$ or creating stable coexistence groups.

(2) Hands and respiratory hygiene

(3) Sufficient ventilation and frequent cleaning of the schools

(4) Adequate and early management of patients

According to that document, each center had to have a Plan for the Beginning of the School Year and a Contingency Plan. It proposed the creation of COVID19 teams within schools with members from different areas (management board, cleaners, families, students) to ensure the accomplishment and communication of the key goals.

A 26-page document listed detailed measures that described how to implement these four key guidelines to prevent the spread of COVID-19 in schools. As mentioned before in this chapter, the Ministry for Education and Vocational Education and Training offered national guidelines, but the responsibility to act in Spanish education was transferred to the Autonomous Communities.

During the next few weeks, the speed of the political actions taken to implement these measures in each of the regions had a direct effect on the milestones for the next school year starting in September 2020 (Trujillo, 2020).

It is very difficult to consolidate the decisions of the different Autonomous Communities during the summer of 2020:

- Several instructions, documents, and laws were published to modify previous versions.

- The media reported political decisions or ideas that were not sustained by official laws, had no assigned budget, and/or had no deployment plan.

- There were backstage actions that were not publicized or programmed: safety equipment or money, e.g., was suddenly sent to schools.

Each Autonomous Community published the definitive instructions that were to be considered by the schools to organize the school year at different times. There was also great variability in the dates when material and human resources would be made available to schools. 
In the case of the Autonomous Community of Madrid, at the beginning of July 2020 the instructions (VICECONSEJERÍAS DE POLÍTICA EDUCATIVA Y DE ORGANIZACIÓN EDUCATIVA, 2020 B) established four possible scenarios:

- Scenario I: Extraordinary hygiene scenario. This was the initial planned scenario for the school year 2020-2021. Hygiene had to be guaranteed. If the distance of $1.5 \mathrm{~m}$ between the members of the academic community could not be maintained, masks had to be worn.

- Scenario II: If the health crisis worsened, face-to-face lessons would be cancelled. In Primary Education, the groups of students had to be in stable coexistence groups of a maximum of 20 pupils. In Secondary Education, students had to be offered between 30 and $50 \%$ of their lessons in person, while the rest could be offered remotely.

- Scenario III: Lockdown. All teaching would be offered remotely. The LMS Educamadrid would offer online exams.

- Scenario IV: Normality. The COVID-19 problem disappeared, and standard in person education would resume.

Considering that in July, Madrid planned for Scenario I for the 2020-2021 school year, the schools' organization instructions were very similar to those published during previous non-COVID-19 school years (VICECONSEJERÍAS DE POLÍTICA EDUCATIVA Y DE ORGANIZACIÓN EDUCATIVA, 2020 C).

Several organizations noted the need to increase resources to guarantee health and teaching conditions during the coming school year. For example, ADIMAD, the Association of High School Principals in Madrid, mentioned it was impossible to guarantee distances of $1.5 \mathrm{~m}$ under the standard conditions and requested more teachers to handle the academic deficits created by the pandemic (Torres Benayas, 2020).

In Madrid, during July 2020, all the planning and organization of the new school year was done mainly under pre-pandemic conditions and with no useful increase of material and human resources.

In a press release on August 25th, the President of the Autonomous Community of Madrid-Isabel Ayuso-informed that the new school year would start with Scenario II, and new material and human resources would be assigned (Ayuso, 2020). This announcement modified the initial instructions to increase protection measures, but this modified version still assumed Scenario I as the official starting situation (VICECONSEJERÍAS DE POLÍTICA EDUCATIVA Y DE ORGANIZACIÓN EDUCATIVA, 2020 D).

As result of the coordination with 17 Autonomous Communities, the Ministry of Education and Vocational Education and Training published the agreement to adopt public health coordinated actions during the 2020-2021 school year on August 27th (MEFP, 2020C).

Despite this agreement, the plans of the 17 Autonomous Communities had differences. Navarra, Castilla y León, and País Vasco continued offering 100\% instruction in person while the remaining communities combined online teaching at different levels (Sánchez Caballero, 2020). ACADE, the Association of Private 
Schools, demanded similar criteria nationwide, eliminating region-specific guidelines (ACADE, 2020).

To increase the distance between students, smaller student groups were created, increasing demand for teachers throughout the country. This increase in the demand for teachers created a deficit in several regions that competed to attract human resources.

In September 2020, the Spanish Government transferred COVID-19 funds to each Autonomous Community to finance actions in education (Ministerio de Hacienda, 2020) (Table 11.1).

PROA + (20-21) was a national fund implemented to finance orientation, progress, and enrichment of education from the COVID_19 emergency (Secretaría de Estado de Educación, 2020) (Table 11.2).

The extraordinary amounts assigned to education during the pandemic represent around $0.2 \%$ of the GDP. As a result, there has been an increase of the total Spanish education budget from 4.2 to $4.4 \%$ of the GDP (Consejo Escolar del Estado, 2021).

FEDADi, the Spanish Federation of Public Schools Principals' Associations, prepared a report in October 2020 that described the beginning of the school year in Spain (FEDADi, 2021). Nearly all the Autonomous Communities modified their

Table 11.1 COVID-19 funds to finance actions in education

\begin{tabular}{|c|c|}
\hline $\begin{array}{l}\text { Autonomous communities and } \\
\text { cities of Ceuta and Melilla }\end{array}$ & Amounts (thousand euros) \\
\hline Cataluña & $337.438,19$ \\
\hline Galicia & $92.987,53$ \\
\hline Andalucía & $383.856,98$ \\
\hline Principado de Asturias & $32.529,93$ \\
\hline Cantabria & $22.141,31$ \\
\hline La Rioja & $13.204,99$ \\
\hline Región de Murcia & $73.820,12$ \\
\hline Comunitat Valenciana & $214.185,03$ \\
\hline Aragón & $53.448,02$ \\
\hline Castilla-La Mancha & $89.185,60$ \\
\hline Canarias & $87.368,30$ \\
\hline Extremadura & $43.295,39$ \\
\hline Illes Balears & $50.280,26$ \\
\hline Madrid & $291.696,57$ \\
\hline Castilla y León & $84.043,55$ \\
\hline País Vasco & $87.230,70$ \\
\hline Navarra & $29.287,53$ \\
\hline Melilla & $7.000,00$ \\
\hline Ceuta & $7.000,00$ \\
\hline Total & $2.000 .000,00$ \\
\hline
\end{tabular}


Table 11.2 Budget of PROA $+(20-21)$

\begin{tabular}{l|l}
\hline Autonomous community & Amount (euros) \\
\hline Andalucía & $5.345 .935,00$ \\
\hline Aragón & $1.750 .588,00$ \\
\hline Asturias (Principado de) & $1.549 .524,00$ \\
\hline Balears (Illes) & $2.002 .454,00$ \\
\hline Canarias & $1.963 .638,00$ \\
\hline Cantabria & $1.471 .583,00$ \\
\hline Castilla y León & $2.152 .493,00$ \\
\hline Castilla-La Mancha & $2.145 .005,00$ \\
\hline Cataluña & $4.516 .098,00$ \\
\hline Comunitat Valenciana & $3.439 .736,00$ \\
\hline Extremadura & $1.677 .069,00$ \\
\hline Galicia & $2.374 .545,00$ \\
\hline Madrid (Comunidad de) & $3.768 .353,00$ \\
\hline Murcia (Región de) & $2.230 .945,00$ \\
\hline Navarra (Comunidad Foral de) & $2.032 .957,00$ \\
\hline La Rioja & $1.579 .077,00$ \\
\hline Totales & $40.000 .000,00$ \\
\hline
\end{tabular}

previsions from July. $60 \%$ of them changed the school year start date. Teaching was heterogenous, with different amounts of classroom and online teaching depending on the different communities and levels. In some regions, face-to-face teaching was authorized once lessons had already started, discriminating against schools that were not able to adapt. In nearly all cases, the administration had been in contact with the educators' associations, but in general it did not establish agreements with social stakeholders.

FEDADi notes that the number of teachers increased in most cases, reducing the student-to-teacher ratio. In some communities, it was very difficult to hire personnel for specific subjects. Protocols were constantly adapted to the pandemic situation, increasing stress for the entire education community in the school. The responsibility was mainly on the management teams, sometimes supported by specific personnel. Around $20 \%$ of schools considered using additional facilities outside their standard location. Nearly all administrations provided hygienic and health protection material, but only around half of them provided technological equipment. The decision of whether to use official online platforms or other tools was not unanimous. There were very few specific compulsory training activities, but there was a great range of elective courses. There was no increase in the number of school buses. Some of the communities decided to cancel services like the canteens and libraries. The extracurricular activities were mostly all cancelled. The inspection services offered heterogeneous approaches and FEDADi mentioned it would have been useful to reduce bureaucracy and increase collaboration. 
Student academic achievement seems to have decreased. Ferrero mentioned that Adimad stated that students in 3rd ESO (between 14 and 15 years old) appeared to have failed $15 \%$ or $20 \%$ more subjects during the first trimester (SeptemberDecember 2020) compared to the same period in 2019 (Ferrero, 2021).

Sanz, Cuerdo, and Doncel (2020) concluded that "during the closure of the centers due to COVID-19, there was a notable increase in the use of digital resources compared to the last five years, although this increase was not homogeneous between applications or between regions. However, in Spain there was no divergence in access to digital educational resources due to the level of family income, at least regarding free access digital educational resources."

The State Education Council published the first version of its report of the postpandemic Spanish educational situation in January 2021 (Consejo Escolar del Estado, 2021). This report mentioned that in November, only $0.09 \%$ of schools closed because of COVID-19 cases after opening in September and 13.37\% had classrooms under quarantine. Considering the data, the incidence of the pandemic at schools was lower than the general average. The age group with the highest incidence of contagion (ages 15 to 29 years old) caught COVID-19 at social and familial activities, but not at schools. This suggests that school precautionary measures were successful.

\subsection{Conclusions}

The education measures adopted during the COVID-19 pandemic should be analyzed in two different periods: until the end of the 2019-2020 academic year (March to July 2020) and during the first trimester of the 2020-2021 school year (September to December 2020). During the first period, most face-to-face instruction was suspended and repliced by online modalities. In some cases, small groups in Bachillerato returned to the classrooms in June to prepare for the university access EBAU exam. During the second period, students mostly returned to the classrooms with health risk control measures (masks, security distance, intense disinfection and ventilation, small "bubble" groups within classrooms, etc.)

In both cases, it is possible to draw several conclusions about the measures taken. We will try to examine the causes and present the consequences elicited in each set of measures.

(1) In Spain, measures were taken late. There were no proactive policies; actions were slowly reactive to the pandemic development, with no previous plan of action. In January 2020, the Spanish government learned about the situation in China $^{7}$ and Italy (a neighboring country with many international exchanges

\footnotetext{
${ }^{7}$ In January, a large number of reports warned of the seriousness of the situation, like those transmitted by the workplace hazard prevention service of the national police (Servicio de Prevención de Riesgos Laborales de la Policía Nacional), the Spanish National Research Council (CSIC) and the National Intelligence Centre (CNI). Also, January 30th the World Health Organization indicated that COVID was a "public health risk of international concern". A confirmation that the existing data
} 
with Spain). ${ }^{8}$ In those places, infected patients, and deaths rapidly increased. The government did not take any precautionary measures with travelers coming from these two countries; for example, temperature checks were not instituted, negative virus tests were not requested (although Italy, for example, had already implemented them).

The borders were not closed, and it was not compulsory for the population to wear protective masks; it was only a recommendation, but there was no insufficient stock to meet the demand for face masks. International sport events (like the ValenciaInter Milan soccer Champions League match on March 6th), political meetings (Vox party in Vista Alegre, Madrid on March 8th), public festivals like the Mascletá in Valencia and the feminist demonstrations to celebrate the 8th of March (attended by many government members) continued to take place. Only one major event, the Mobile World Congress of Barcelona, planned for the 24 to 27th of February, was cancelled on February 12th, but the decision was made by the organizers and not by the health authorities. It was not until the state of emergency on March 14th that implementation of those measures began.

(2) Measures were taken with no political consensus. The political stakeholders did not assure a trustworthy and responsible national behavior. The government's strategy did not have the approval of the parties in the opposition nor support from some regional institutions; different Autonomous Communities took actions that did not coincide with the national government proposals. The strategy should have been national, but it was strongly criticized because there was no consensus, and it was undermined by the regional governments. Some critics were regional Presidents belonging to the majority party (as the case of Emiliano García-Page, regional President of Castilla-La Mancha, from the Socialist Party). ${ }^{9}$

There was no consensus between the central government and the governments of the Autonomous Communities. The different political parties did not agree on

\footnotetext{
urged action before March (44 days after the WHO's alert) is that February 12th, John Hoffman, organizer of the Mobile World Congress, announced the cancelation of the event (expected to attract 100.000 visitors from all over the world to Barcelona). As a result of this announcement the Spanish Health Minister mentioned that "There is no public health reason that prevents celebrating an event of these characteristics in our country".

https://www.elespanol.com/espana/20200331/informes-oficiales-gobierno-desdeno-efecto-dem oledor-coronavirus/478703438_0.html.

https://www.larazon.es/espana/20200324/3tbo4izi6zdttpijmbpgbzogdi.html. https://okdiario.com/investigacion/cni-traslado-preocupacion-delegacion-pekin-sobre-covid-19pero-moncloa-ignoro-5499913.

${ }^{8}$ At the end of February Italy already had 900 cases, 21 deceases and specific measures were already in place in some areas of the country.

${ }^{9} \mathrm{https} / / /$ www.efe.com/efe/espana/politica/page-reclama-una-estrategia-nacional-mas-meticulosay-decidida-contra-el-virus/10002-4383874.
} 
basic common actions (for example, even votes in the National Parliament regarding declaration of a state of emergency were far from unanimous). ${ }^{10}$

Spanish Education and Health Care decentralization hindered agreement on safety measures, such as deciding and organizing the acquisition of protective equipment like masks for health professionals and the general public or the acquisition of ventilators for hospital emergency units.

High political polarization also hindered consensus. The Spanish parliament after the 2019 election represents 16 political parties (Parlamento Español, 2019). The parties Podemos (a radical left-wing party) and Vox (a radical right-wing party) defend extreme opposite ideas and foment the division of the chamber in two blocks. The government of PSOE and Podemos depends on the constant support of several parties of the Congress Chamber to achieve the necessary majority to approve each decision.

(3) Instructions were improvised; it was difficult to determine outcomes. At the beginning, the actions taken were late and erratic; an example was the constantly changing information provided by the central and regional governments. The constant updates indicated that the policies were reactive and neither meditated, proactive, nor strategic.

(4) There was considerable misinformation that led to uncertainty. At the beginning of the pandemic, there was no conceptualization of how the school year would end. There was also a great deal of uncertainty about the conditions to return to face-to-face teaching; many of the instructions and measures were not ready until a few days before the start of the 2020-2021 school year. The lessons from the first wave should have been learned from March to June, but uncertainty remained until the beginning of September, the month when classes traditionally resume. Consequently, the school year was delayed, and school actions were hastily adopted.

(5) Low ICT skills of the teachers and students. The teachers did not have sufficient digital competence that could help them develop online classes during the lockdown. Some homes had insufficient ICT resources, but the impact on lowincome households was less than expected. "In Spain there was no divergence in access to digital educational resources due to the level of family income, at least with regard to free access digital educational resources." (Sanz, Cuerdo, \& Doncel, 2020)

(6) The individual effort of the management teams of the schools and teachers was considerable and very positive. The personnel of the schools were able to offer an alternative education with distance teaching. Their ability to provide learning options has been critical to develop the key actions needed to provide online teaching first and to prepare the classrooms for safe face-to-face teaching after the lockdown. The schools have worked reasonably well thanks to its personnel and despite the political mismanagement.

\footnotetext{
${ }^{10}$ Results in October 29th vote in the National Parliament to prorogation Alarm State was 194 in favour and 152 not in favour (against or abstention).
} 


\section{References}

ACADE. (2020, September 18). ACADE solicita al ministro de Sanidad medidas para paliar el impacto de la pandemia en los centros educativos. Retrieved from https://educacionprivada.org/ noticia/2020-09-18/27546.

Antiñolo, J., Molina, M. D., \& Pérez, A. (2014). Challenges in times of recession in Spain. In S. J., \& L. L., Challenges to Teacher Education in Difficult Economic Times: International Perspectives (pp. 77-92). Routledge.

Ayuso, I. (2020, August 25). Comunidad de Madrid. Retrieved from https://www.comunidad.mad $\mathrm{rid} /$ notas-prensa/2020/08/25/comunidad-madrid-contratara-casi-11000-profesores-hara-testcovid-19-docentes-estudio-serologico-alumnos-colectivos-riesgo.

BOE. (2006, May 3). Retrieved from https://www.boe.es/eli/es/lo/2006/05/03/2/con.

BOE. (2020, December 29). Ley Orgánica 3/2020. Retrieved from https://www.boe.es/diario_boe/ txt.php?id=BOE-A-2020-17264.

Boletín Oficial del Estado. (2020, March 14). BOE. Retrieved from https://www.boe.es/buscar/ doc.php?id=BOE-A-2020-3692\#: :text=Real\%20Decreto\%20463\%2F2020\%2C\%20de,Public ado $\% 20$ en $\% 3$ A\&text $=67 \% 2 \mathrm{C} \% 20 \mathrm{de} \% 2014 \% 20 \mathrm{de} \% 20$ marzo,a $\% 2025400 \% 20(11 \% 20 \mathrm{p} \% \mathrm{C} 3 \%$ A1gs.\%20).

Comunidad Autónoma de Madrid. (2020, March 9). Retrieved from https://www.comunidad.mad $\mathrm{rid} /$ noticias/2020/03/09/comunidad-madrid-aprueba-medidas-extraordinarias-coronavirus.

Consejo Escolar del Estado. (2020, April 7). actuaciones en educación que convendría adoptar como consecuencia de la situación creada por la pandemia. Retrieved from http://www.educac ionyfp.gob.es/dam/jcr:dbe9c993-9e6f-46fd-b5fb-604ce4f26a93/propuestas-cee-7-abril.pdf.

Consejo Escolar del Estado. (7 de April de 2020). actuaciones en educación que convendría adoptar como consecuencia de la situación creada por la pandemia. Obtenido de http://www.educacion yfp.gob.es/dam/jcr:dbe9c993-9e6f-46fd-b5fb-604ce4f26a93/propuestas-cee-7-abril.pdf.

Consejo Escolar del Estado. (2021). Situación actual de la educación en España a consecuencia de la pandemia-Avance 15 de Enero. Ministerio de Educación y Formación Profesional.

Constitución Española. (1978). Retrieved from https://www.boe.es/buscar/act.php?id=BOE-A1978-31229.

de Olagüe-Smithson, C. (2019). Vocational education in Europe. KDP.

Diario oficial de la Generalitat Valenciana. (2020 B, July 30). Instrucciones para la organización y el funcionamiento de los centros que imparten Educación Secundaria Obligatoria y Bachillerato durante el curso 2020-2021. Retrieved from https://www.dogv.gva.es/datos/2020/ 07/30/pdf/2020_6219.pdf.

Diario oficial de la Generalitat Valenciana. (2020, July 22). Instrucciones para la organización y el funcionamiento de los centros que imparten Educación Infantil de segundo ciclo y Educación Primaria durante el curso 2020-2021. Retrieved from https://www.dogv.gva.es/datos/2020/07/ 22/pdf/2020_5929.pdf.

DIRECCIÓN GENERAL DE EDUCACIÓN SECUNDARIA, FORMACIÓN PROFESIONAL Y RÉGIMEN ESPECIAL. (2020, May 22). INSTRUCCIONES SOBRE EVALUACIÓN FINAL, PRUEBAS DE ACCESO Y PRUEBAS PARA LA OBTENCIÓN DE TÍTULOS Y CERTIFICADOS. Retrieved from https://www.educa2.madrid.org/web/educamadrid/principal/files/239 a744a-d47d-430b-a64d-a7c5e0484688/2020-05-22_INSTRUCCIONES_DGESFPRE_EVAL UACION_FINAL_PRUEBAS_CURSO_2019-2020\%20POR\%20COVID-19.pdf?t=159033443 6094.

Egido, I. (2005). Transforming education. The Spanish experience. Nova Science.

Egido, I., \& Valle, J. M. (2015). Spain: Education and regional autonomy. In T. Corner, Education in the European Union. Pre-2003 Member States (pp. 165-284). London: Bloomsbury Academic. doi:ISBN: 978-147-2528-155.

FEDADi (2021) Informe sobre el inicio de curso 2020-2021. Retrieved from http://www.fedadi. org/? $\mathrm{p}=2421$. 
Fernández Enguita, M. (2020, March 31). Una pandemia imprevisible ha traído la brecha previsible. Retrieved from https://blog.enguita.info/2020/03/una-pandemia-imprevisible-ha-traido-la.html.

Ferrero, B. (2021, January 20). Los alumnos de 14 y 15 años sufren la pandemia: un 20\% más de suspensos en el primer trimestre. Retrieved from El Pais: https://elpais.com/espana/madrid/ 2021-01-19/los-alumnos-de-14-y-15-anos-sufren-la-pandemia-un-20-mas-de-suspensos-en-elprimer-trimestre.html.

Hodges, C., Moore, S., Lockee, B., Trust, T., \& Bond, A. (2020, March 27). The Difference Between Emergency Remote Teaching and Online Learning. Retrieved from Educause Review https://er.educause.edu/articles/2020/3/the-difference-between-emergencyremote-teaching-and-online-learning.

Marco, L. (2020, July 2). El Gobierno valenciano se desmarca del resto de autonomías e invertirá 200 millones para aumentar profesorado y reducir la ratio de alumnos por aula. ElDiario.es. Retrieved from ElDiario.es https://www.eldiario.es/comunitat-valenciana/educacion-invertiramillones-profesorado-monitores_1_6076198.html.

MEFP. (2020). Retrieved from https://www.educacionyfp.gob.es/inee/evaluaciones-nacionales/.

MEFP. (2020 B, June 22). MEDIDAS DE PREVENCIÓN, HIGIENE Y PROMOCIÓN DE LA SALUD FRENTE A COVID-19 PARA CENTROS EDUCATIVOS EN EL CURSO 20202021. Retrieved from http://www.educacionyfp.gob.es/prensa/actualidad/2020/06/20200623-gui aprevencioncursonuevo.html.

MEFP. (2020 C, August 27). Declaración de actuaciones coordinadas en Salud Pública frente al COVID-19 para centros educativos. Retrieved from https://www.lamoncloa.gob.es/serviciosdep rensa/notasprensa/educacion/Paginas/2020/270820-covid-curso.aspx.

Ministerio de Hacienda. (2020, September 2). Orden HAC/809/2020, de 1 de septiembre, por la que se determina la cuantía de la distribución definitiva entre las Comunidades Autónomas y Ciudades de Ceuta y Melilla de los recursos previstos en la letra c) del apartado 2 del artículo 2 del RD 22/2020. Retrieved from https://www.boe.es/eli/es/o/2020/09/01/hac809.

OECD. (2009). OECD reviews of tertiary education: Spain 2009. OECD.

Ossenbach, G. (1996). Democratisation and Europeanisation: Challenges to the Spanish educational system since 1970. In D. Benner \& D. Lenzen (Eds.), Education for the New Europe (pp. 93-105). Berghahn Books.

Parlamento Español. (2021). Retrieved from https://www.congreso.es/web/guest/busqueda-de-dip utados?onlyDiputadas $=$ true.

Sánchez Caballero, D. (2020, November 9). Solo tres comunidades resisten con clases $100 \%$ presenciales mientras se agudizan las restricciones por la pandemia. Retrieved from elDiario.es https://www.eldiario.es/sociedad/tres-comunidades-resisten-clases-100-presen ciales-agudizan-restricciones-pandemia_1_6389117.html.

Santos-Montealegre, E. (2020). Historias de una pandemia. Adiós 2020. KDP.

Sanz, I., Cuerdo, M., \& Doncel, L. M. (2020). El Efecto Del Coronavirus En El Aprendizaje De Los Alumnos: Efecto En El Uso De Recursos Digitales Educativos. Papeles De Economía Española(166), 3-17. doi:ISSN: 0210-9107.

Secretaría de Estado de Educación. (2020, August 13). distribución resultante del crédito destinado en el año 2020 al Programa de cooperación territorial para la orientación, avance y enriquecimiento educativo en la situación de emergencia educativa del curso 2020-21 provocada por la COVID-19 PROA+ (20-21). Retrieved from BOE https://www.boe.es/eli/es/res/2020/07/31/(9).

Torres Benayas, V. (2020, July 24). “No queremos ser cómplices”: los institutos de Madrid se plantan ante la falta de medidas para septiembre. Retrieved from El País https://elpais.com/espana/madrid/2020-07-24/no-queremos-ser-complices-los-institutosde-madrid-se-plantan-ante-la-falta-de-medidas-para-septiembre.html.

Trujillo, N. L. (2020, August 19). Vuelta al colegio en septiembre: este es el plan en cada comunidad autónoma. Retrieved from Newtral https://www.newtral.es/medidas-covid-colegios-educacioncomunidades-autonomas/20200819/.

Viceconsejería De Política Educativa. (2020a, April 21). Resolución De La Viceconsejería De Política Educativa Por La Que Se Dictan Instrucciones Para El Desarrollo Del Tercer Trimestre 
y Final Del Curso. Retrieved from https://www.comunidad.madrid/sites/default/files/doc/educac ion/20.04_resolucion_final_curso_covid-19.pdf.

Viceconsejerías De Política Educativa y De Organización Educativa. (9 de Julio de 2020b). Instrucciones Sobre Medidas Organizativas y De Prevención, Higiene y Promoción De La Salud Frente a COVID-19 Para Centros Educativos En El Curso 2020 2021. Obtenido de https://www.comunidad.madrid/sites/default/files/20.07_resolucion_conj unta_covid-19_para_centros_educativos_en_el_curso_2020-2021.pdf.

Viceconsejerías De Política Educativa y De Organización Educativa. (2020c, March 11). Resolución Conjunta De Las Viceconsejerías De Política Educativa y De Organización Educativa Que Modifica La Resolución Del 10 De Marzo De 2020. Retrieved from https://www.comunidad.mad $\mathrm{rid} / \mathrm{sites} / \mathrm{default} / \mathrm{files} /$ doc/educacion/2020.03.12_modificacion_resolucion_conjunta_viceconsej eras_covid-19_.pdf.

Viceconsejerías De Política Educativa y De Organización Educativa. (2020d, July 9). Instrucciones Sobre Comienzo De Curso Escolar 2020-2021. Retrieved from https://www.comunidad.madrid/ sites/default/files/20.07_resolucion_conjunta_instrucciones_inicio_de_curso_20.21.pdf.

Viceconsejerías De Política Educativa y De Organización Educativa. (2020e, August 28). Resolución Por La Que Se Modifican Las Instrucciones Del 9 De Julio De 2020. Retrieved from https://www.comunidad.madrid/sites/default/files/doc/educacion/2020-08-28_ resolucion_conjunta_modifica_09-07-2020_covid-19.pdf.

Viceconsejerías De Política Educativa y De Organización Educativa. (2020e, May 17). Instrucciones Para La Puesta En Marcha De Las Actividades Permitidas En Las Fases 0 Y I. Retrieved from https://www.comunidad.madrid/sites/default/files/doc/educacion/20.05._resolu cion_reincorporacion_a_los_centros_educativos._covid-19.pdf.

Viceconsejerías De Política Educativa y De Organización Educativa. (2020f, March 10). Resolución Conjunta De Las Viceconsejerías De Política Educativa y De Organización Educativa Sobre Instrucciones De Funcionamiento De Los Centros Educativos Afectados Por Las Medidas Contenidas En La Orden 338/2020, De 9 De Marzo. Retrieved from https://www.comunidad.madrid/sites/default/files/doc/educacion/2020.03_res olucion_conjunta_instrucciones_coranovirus.pdf.

Zubillaga, A., \& Gortazar, L. (2020). COVID 19 Y EDUCACIÓN I: problemas, respuestas y escenarios. Fundación Cotec para la innovación.

Javier M. Valle Awarded the "Pedro Rosello" Award (Best Spanish Doctoral Thesis in Comparative Education). Professor at UAM University, specializing in Supranational Education (particularly in the European Union). Director of the UAM Research Group on Education Policy Supranational (GIPES). EURYDICE advisor. TEAM-EUROPE member. Vice President of SEEC. Director of the Journal of Supranational Policies of Education and Co-Director of the Spanish Journal of Comparative Education, REEC. Member of the Education Council of the Community of Madrid.

Carlos de Olagüe-Smithson Principal at the IES Pedro de Tolosa High School and part-time professor at the Carlos III University. Member of the UAM Research Group on Education Policy Supranational (GIPES), ADIMAD, Association of High School Principals, and responsible for international affairs in FP Empresa (VET Spanish association). Erasmus and VET expert. 
Open Access This chapter is licensed under the terms of the Creative Commons Attribution 4.0 International License (http://creativecommons.org/licenses/by/4.0/), which permits use, sharing, adaptation, distribution and reproduction in any medium or format, as long as you give appropriate credit to the original author(s) and the source, provide a link to the Creative Commons license and indicate if changes were made.

The images or other third party material in this chapter are included in the chapter's Creative Commons license, unless indicated otherwise in a credit line to the material. If material is not included in the chapter's Creative Commons license and your intended use is not permitted by statutory regulation or exceeds the permitted use, you will need to obtain permission directly from the copyright holder.

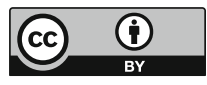

